\title{
MODELING THE PROFITABILITY OF LOAN OPERATIONS CORPORATE CLIENTS
}

\author{
V. G. Mokhov ${ }^{1}$, mokhovvg@susu.ru, \\ Ya. E. Katernoga ${ }^{2}$, masnayayana@mail.ru \\ ${ }^{1}$ South Ural State University, Chelyabinsk, Russian Federation \\ 2 PJSC "Sberbank of Russia", Chelyabinsk, Russian Federation
}

\begin{abstract}
The article is devoted to the optimization of the bank's operating ac-tivities on the basis of mathematical modeling of the assessment of the future profitability of corporate clients in the implementation of credit transactions in order to increase the efficiency of decisions taken in the implementation of transactions that carry credit risk. The modeling is based on the use of the forecasted rate of return on risk-weighted assets - PRoRWA (predicted RoRWA) - the predicted value of the RoRWA indicator for the client for the next "rolling year" taking into account the assessment of the profitability of a new potential credit transaction. The modeling process takes into account the assessment of the total profitability of the client for the bank, including income from cross-sales - the additional income of the bank in the implementation of a particular transaction. The proposed model was tested at one of the divisions of a commercial bank. The simulation results are recommended for use in pricing in the process of setting the limit values of the marginality of transactions for corporate clients, in assessing the level of risks assumed by the bank in the implementation of new credit transactions, as well as in the analysis of alternative options for increasing the profitability of the bank's equity capital.
\end{abstract}

Keywords: modeling; optimization; bank; total profitability; cross-selling; credit operations; financial risks; forecasting.

\section{Introduction}

The management of banking institutions is primarily associated with the integration of strategic policies aimed at maximizing the income from the loan portfolio of investments and minimizing costs for various categories of earned resources. According to many experts in this field, the management of the bank's assets and liabilities largely depends on the optimization of the bank's operating activities when working with corporate clients, especially when implementing large credit transactions [1-5]. In the context of the current restrictions of banking institutions "from above" - market conditions and proposals of competitors and "from below" - strict requirements of the regulator, the Central Bank of Russia, improving the operational efficiency of a commercial bank to maintain its license has become especially relevant.

\section{Algorithm and Mechanism of Modeling}

In the current conditions of constant changes in both the requirements of the regulator and the financial services market itself, it is important to have an idea not only about the current profitability of the client per unit of consumed regulatory capital, but also to understand how this indicator may change in the future when decisions on the implementation with the client of new transactions that carry credit risks to the 
bank. This goal can be achieved through the use of the predicted rate of return on riskweighted assets - PRoRWA (predicted RoRWA) - the forecasted value of the RoRWA indicator for the client for the next "rolling year", taking into account the assessment of the profitability of a new potential credit transaction. At the same time, the assessment of the total profitability of the client for the bank, including the income from cross-selling - the additional income of the bank in the implementation of a particular transaction, is of great importance here. The algorithm for assessing the client's future profitability after the implementation of a new credit transaction is shown in Fig. 1.

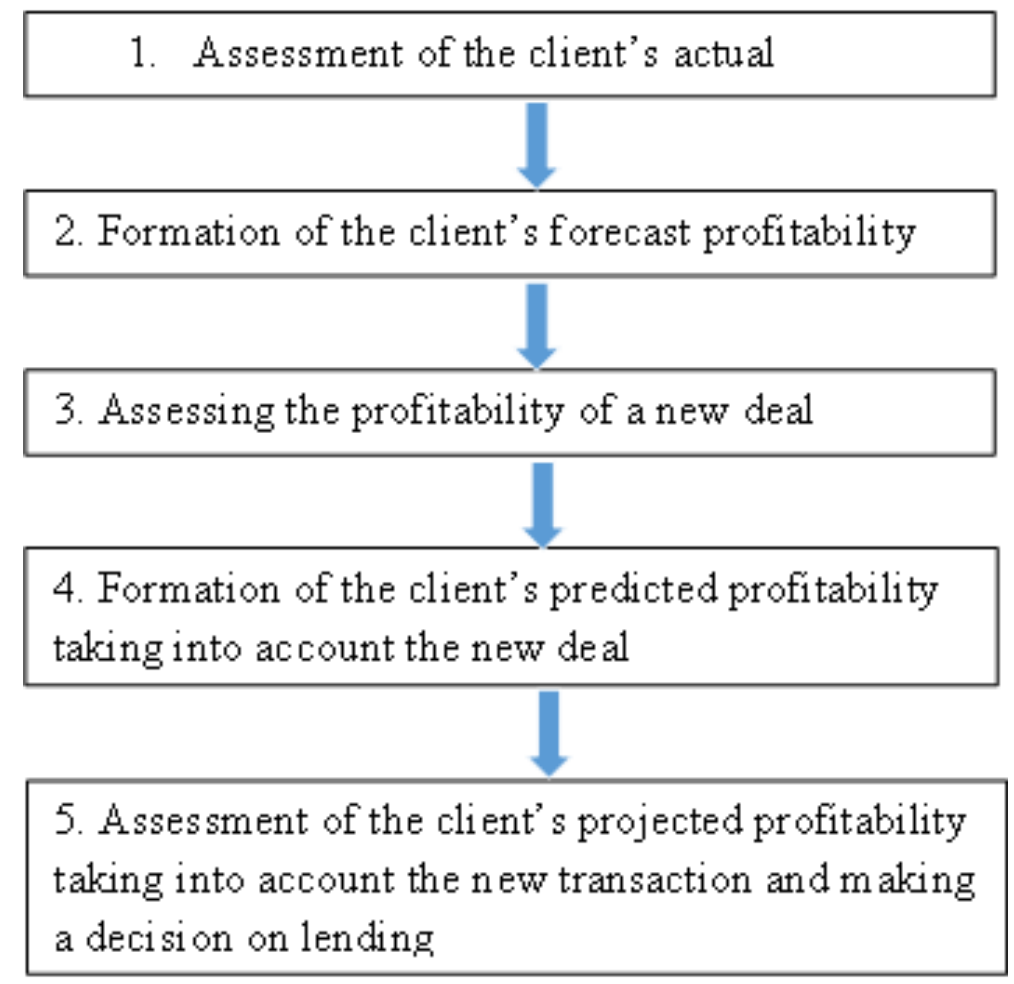

Fig. 1. Algorithm for assessing the client's future profitability

RoRWA is an indicator of how much a client brings in income per unit of consumed regulatory capital, which is a measure of risk assessment according to the rules of the regulator. Operating income received by a bank and included in RoRWA numerator, includes 3 components: net interest income from active operations (NPDA), net interest income from passive operations (NPIR), and net commission income on off-balance sheet transactions. NPDA from lending to a client is calculated using the formula (1).

$$
C H P D A=P D-S F-S F R+K D C H P D-O P E X-E L,
$$

where PD is the interest income from lending to the client, obtained by multiplying the average balance of the client's loan debt to the bank for a certain period by the interest rate under the loan agreement; $\mathrm{SF}$ - the cost of funding the client's urgent loan debt; SFR - cost of reserve funding; KDCHPD - commission income from the client's lending operations; EL - expected losses, representing an estimate of the average expected level of losses for a client based on his riskiness, portfolio structure over a period of 1 year from the date of assessment / calculation. 
The EL indicator is defined as the product of three indicators: PD, LGD, EAD. PD (Probability of Default) is the probability of the borrower's inability to meet its obligations with a forecast horizon of one year. Determined using a probability of default estimation model. The calculation of banks' PD-models rating is based on a set of customer characteristics, broken down into 3 main groups: financial (revenue, debt level); nonfinancial (company lifetime); behavioral (using previous lines of credit). PD is uniquely linked to the current rating scale in a bank, in which each rating has its own PD level (Fig. 2).

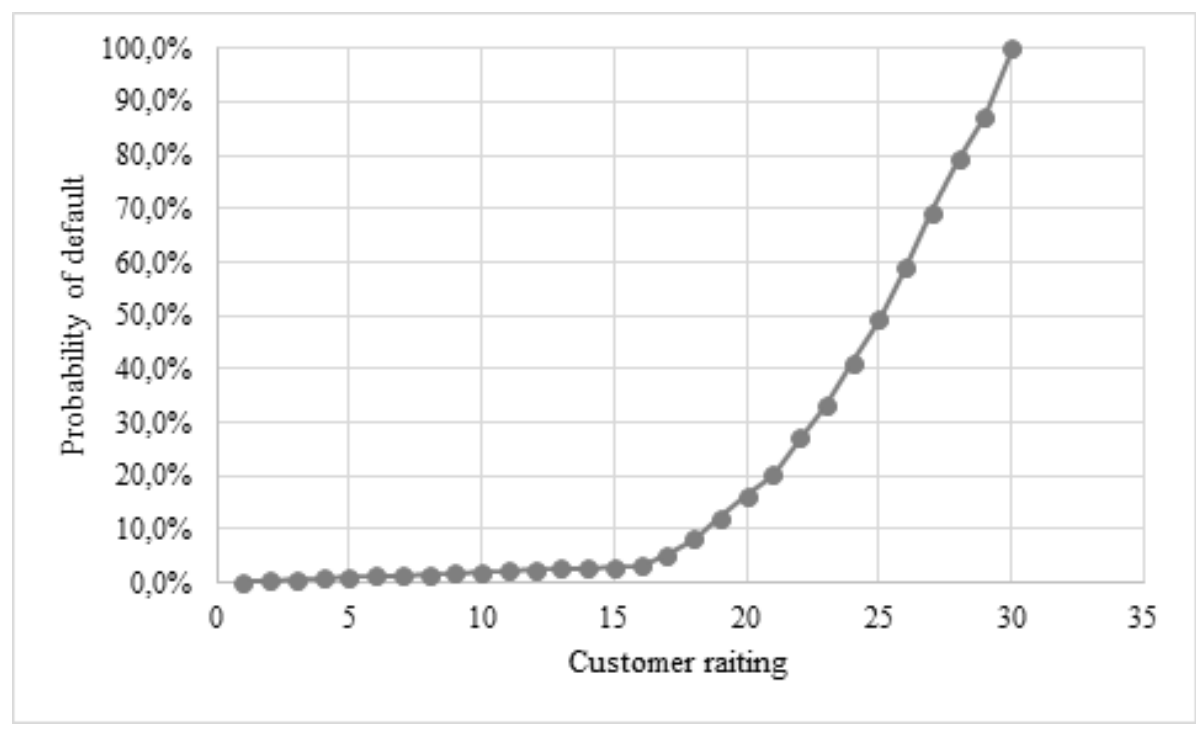

Fig. 2. Dependency example

LGD is the share of losses in the event of a default by a counterparty or the proportion of the amount at risk in the event of a default that is lost in the event of a default. Modeled using the recovery rate, i.e. on the premise that part of the default loans will be repaid. The calculation of the collateral reimbursement usually occurs together with the LTV (Loan-to-value). It is assumed that one of 3 things can happen to the loan:

- restructuring (recovery, that is, full repayment of the loan by the borrower on his own);

- cession (transfer of debt);

- sale (write-off of debt or sale of collateral).

LGD models are built on the probabilities of outcomes and losses in their implementation.

In theory, LGD is calculated in different ways, but the most popular is the "gross" LGD, where the total loss is divided by the value at risk (EAD). Another method is to split the losses into the unsecured portion of the line of credit (where the collateral covers part of the EAD). If the collateral value is zero, then LGD is equivalent to gross LGD. To do this, you can use various types of statistical methods. Gross LGD is most popular among scientists because of its simplicity and because scientists only have access to data on the bond market, where collateral value is often unknown, not calculated, or has no significant impact. 
EAD, or Value at Risk of Default, is the amount owed by the borrower at the time of default. It is calculated according to formula (2) as the remaining amount of debt at risk, predicted for a loan that defaults with a forecasting horizon of one year.

$$
E A D=\text { Currentdebt }+C C F \cdot \text { Freelimit }
$$

where CCF is the credit conversion ratio reflecting the possibility of withdrawing additional credit funds by the borrower by the time of default and the transition of the corresponding off-balance sheet liabilities of the borrower to the balance sheet. Its value was determined based on the analysis of statistical data on the bank's loan portfolio. Net interest income from attracting client funds is estimated using the formula (3).

$$
C P D P=T D-F O R-P R-O P E X
$$

where TD is the transfer income received by the bank for attracting customer funds; FOR the cost of contributions to the mandatory reserve fund; PR - interest expenses of the bank from attracting client funds; OPEX - the bank's operating expenses for fundraising operations.

\section{Implementation of the Modeling Mechanism}

We will build a forecast of the bank's economic profit from servicing a corporate client on the basis of retrospective data for 12 months, using the moving average method. The moving average method is represented by formula (4).

$$
Y_{t+1}=m_{t-1}+1 / n \cdot\left(y_{t}-y_{t-1}\right),
$$

where $(t+1)$ is the forecast period; $\mathrm{t}$ - the period preceding the forecast period (year, month, etc.); $Y_{t+1}-$ predicted indicator; $m_{t-1}-$ moving average for two periods preceding the forecast; $\mathrm{n}$ is the number of levels included in the smoothing interval; $y_{t}$ is the actual value of the phenomenon under study for the previous period; $y_{t-1}$ - the actual value of the investigated phenomenon for two periods preceding the forecast.

For the calculation, an odd moving period is taken, equal to 3.

The list of calculation components and the applied methods of forecasting indicators for 12 months are listed in table 1, the actual and forecast indicators of the main components of calculating the client's profitability, taking into account the risk, determined in formula 5 , are reflected in table 2 .

The predicted value of the RoRWA indicator for a transaction is calculated using the formula (5).

$$
P R o R W A_{\text {deal }}=\frac{(P S-S F-C O R-O P E X) \cdot S K+C R}{S K \cdot R W},
$$

where PS is the proposed interest rate on the loan; SF - the cost of funding the loan (estimated transfer rate); COR is the cost of risk, determined by the ratio of the amount of reserves created for a given loan to the amount of this loan; OPEX - operating expenses of the bank, determined as a percentage and associated with the issuance of a loan and the maintenance of the loan agreement; SK - the amount of the loan expected to be issued; 
Methods for predicting indicators for building a model assessing the client's profitability, taking into account the transaction

\begin{tabular}{|c|c|}
\hline Index & Forecast model \\
\hline average balances of assets / liabilities & moving average method with $n=3$ \\
\hline commission revenue & moving average method with $n=3$ \\
\hline operating expenses & moving average method with $n=3$ \\
\hline interest revenue & $\begin{array}{l}\text { product of projected average balances and } \\
\text { interest rates for the last actual period }\end{array}$ \\
\hline interest expenses & $\begin{array}{l}\text { product of the projected average balances } \\
\text { and the funding rate for the last actual } \\
\text { period }\end{array}$ \\
\hline expenses on reserves & $\begin{array}{l}\text { product of projected average balances and } \\
\text { provisioning rates for the last actual period }\end{array}$ \\
\hline expected losses & $\begin{array}{l}\text { product of the projected average balances } \\
\text { and the share of losses in case of default } \\
\text { for the last actual period }\end{array}$ \\
\hline RWA & $\begin{array}{l}\text { product of the average balance for the last } \\
\text { forecast period and the risk-weight for the } \\
\text { last actual period }\end{array}$ \\
\hline
\end{tabular}

$\mathrm{CR}$ - income from the placement of the bank's equity; RW - weight in assets adjusted for risk.

The absolute value of the bank's operating expenses associated with the implementation of the credit transaction and further support of the loan agreement is determined using tabular data on expenses, including the work of credit inspectors to analyze the client's financial situation and build CF-models. In addition, the expenses for employees of the collateral, legal service and security department, who also take part in the analysis of the transaction and preparation of conclusions on the advisability of maintaining relations with the client, corporate underwriting to assess the risks of the transaction, employees of the members of the committee for deciding on the implementation of the transaction, are taken into account, employees of support units that form credit documentation, control the timing and completeness of the client's obligations to the bank.

Assume, the one-time expenses for the issuance of an investment loan in the amount of 1,900 million rubles for a period of 12 months, secured in the form of a surety of an individual, are estimated by the bank in the amount of 350.0 thousand rubles. The costs of the subsequent support of this agreement cost the bank 150.0 thousand rubles. The percentage of operating costs is determined by formula (6).

$$
O P E X=\frac{O P E X_{\text {res }} / 12 \cdot T+O P E X_{\text {out }}}{S K \cdot T \cdot T_{\text {wed }}} \cdot 12 \cdot 100,(\%)
$$

where $O P E X_{\text {res }}$ - operating expenses for support of the loan agreement; $\mathrm{T}$ - loan term; OPEXout - one-time operating costs associated with the implementation of a lending 


\section{Table 2}

Actual and forecast indicators of the main components of calculating the client's profitability, taking into account risk for 12 months

\begin{tabular}{|c|c|c|}
\hline Index & Fact & Forecast \\
\hline Economic profit & -1496.33 & 25815.51 \\
\hline - from the placement of bank funds & -37264.02 & -11590.93 \\
\hline - from the funds raised & 607.30 & 1478.48 \\
\hline - from commission services & 35160.39 & 35927.97 \\
\hline Capital income by client & 35262.93 & 33184.12 \\
\hline RWA & 4670586.46 & 4657419.86 \\
\hline RoRWA, \% & 0.72 & 1.27 \\
\hline
\end{tabular}

transaction; SK - the amount of the credit; $T_{\text {wed }}$ - coefficient of the repayment schedule. The percentage of the OPEX component for determining the PRoRWA for the transaction, calculated using formula 7 , is $0.05 \%$.

Thus, upon receipt of a request from a client for additional financing in the amount of rubles 1.9 billion for investment purposes at a rate of no more than $8.2 \%$ for a period of 12 months, we can calculate its future profitability, taking into account risk-weighted assets according to the above model (assume that the funding rate according to the credit calculator is $6.00 \%$, the cost of credit risk $-0.10 \%$ ).

Income from equity funding of invested funds Equity Funding Income (CR) is calculated using equation (7).

$$
C R=R W A \cdot C E T_{1} \cdot T R_{C A P}
$$

where RWA - risk-weighted assets for deal or customer; $C E T_{1}$ is the target value of the first basic capital adequacy ratio for the group, according to the Central Bank of Russia; $T R_{C A P}$ - the rate of transfer income on equity.

The forecasted volume of return on capital under the transaction according to equation (8) will be equal to 13,167.0 thousand rubles.

As a result, PRoRWA on the transaction will amount to $2.49 \%$, and the client's projected profitability per unit of regulatory capital for the next 12 months, if a new investment loan is issued to the client on the above-described conditions, as the ratio of the amount of the projected income from the client and transaction to the sum of risk-weighted assets for the client and the transaction will be equal to $1.67 \%$.

The client's actual profitability per unit of regulatory capital is $0.72 \%$. This value is mainly due to the negative economic profit of the bank from active operations with the client, taking into account internal fees, expected losses and reserves. The unprofitability of lending operations in this case is explained by the refinancing of the existing loan through its early repayment, when the so-called funding gap occurs

In the forecast period, PRoRWA has a positive trend for the client, mainly due to a decrease in the loss from lending to the client from 37.3 million rubles up to 11.7 million rubles, due to an increase in the load on the client's credit limit and interest income from assets. The absence of a significant increase in the indicator is due to the fact that the 
amount of internal payments for early closing of the credit limit in the forecast period is similar to the actual value. If the value of the specified internal fine in the forecast period were equal to the actual value for the previous month, adjusted to an annual basis, the client's forecast profitability would increase to $2.05 \%$, taking into account the transaction to $2.01 \%$. However, there is no certainty in the absence of early refinancing of the client's current liabilities in the event of a decrease in the key rate or the availability of an offer to refinance a loan at a lower rate from a competing bank. Thus, deliberate overestimation of the indicator in the forecast period may lead to a lack of objectivity in making a decision on lending to a client. The implementation of a new credit transaction with the client will increase the client's profitability per unit of risk-weighted assets up to $1.67 \%$. However, even taking into account the new transaction, the bank's risks for this client are not sufficiently covered by the income received by the bank from servicing the client.

\section{Conclusion}

To increase the level of RoRWA for a client, several options are possible:

- increasing the marginality of a new loan by raising the loan rate in the absence of more competitive offers from other banks;

- implementation of cross-selling by selling a new non-credit product to the client or increasing the bank's share of the client's "wallet" for the current products used. In the case when the indicator of the future profitability of the client is of a sufficiently high level, the bank may revise its standard approaches to pricing and apply individual conditions at the interest rate of this client.

It should be borne in mind that when deciding to expand cooperation with a client, you should not rely only on the predicted level of the RoRWA indicator. It is necessary to take into account the importance of the client for the bank, from the point of view of strategic partnership, the share of this client in the total volume of the bank's portfolio, position in the industry, risks of losing the bank's market share in case of refusal from further cooperation with the client. The developed model is recommended to be used in pricing (setting the limit values of the marginality of transactions for clients depending on its RoRWA level); to assess the level of risks assumed by the bank in the implementation of new credit transactions, as well as when assessing alternative options for increasing the return on the bank's equity capital.

\section{References}

1. Jucan C. N. Strategies for the Management of the Bank's Assets and Liabilities. Annales Universitatis Apulensis Series Oeconomica, 2009, vol. 11, no. 1, pp. 519-524.

2. Georgescu-Golosoiu L. Financial and Banking Definitions. Oscar Print, 2012.

3. Ionel U. Analyzing Banking Risk. "Ovidius" University Annals, Economic Sciences Series, 2013, vol. 13, issue 1, pp. 1549-1553.

4. DeAngelo H., Stulz R. M. W Liquid-Claim Production, Risk Management, and Bank Capital Structure: Why High Leverage is Optimal for Banks. Journal of Financial Economics, 2014, vol. 116, no. 2, pp. 1-50. DOI: 10.1016/j.jfineco.2014.11.011 
5. Slovin M. B., Sushka M. E., Polonchek J. A. The Value of Bank Durability: Borrowers as Bank Stakeholders. Journal of Finance, 1993, vol. 48, no. 1, pp. 247-266. DOI: $10.2307 / 2328888$

Veniamin G. Mokhov, DSc (Economics), Professor, Department of Mathematical and Computer Modelling, South Ural State University (Chelyabinsk, Russian Federation), mokhov50@mail.ru.

Yana E. Katernoga, Master of Applied Mathematics and Computer Science, PJSC "Sberbank of Russia", (Chelyabinsk, Russian Federation), masnayayana@mail.ru.

Received December 1, 2020.

УДК 336.77

DOI: $10.14529 /$ jcem200403

\title{
МОДЕЛИРОВАНИЕ ДОХОДНОСТИ КРЕДИТНЫХ ОПЕРАЦИЙ КОРПОРАТИВНЫХ КЛИЕНТОВ
}

\author{
В.Г. Мохов, Я.Э. Катернога
}

\begin{abstract}
Статья посвящена оптимизации операционной деятельности банка на основе математического моделирования оценки будущей доходности корпоративных клиентов при реализации кредитных сделок для повышения эффективности принимаемых решений при реализации операций, несущих кредитный риск. Моделирование построено на использовании прогнозного показателя доходности риск-взвешенных активов - PRoRWA (predicted RoRWA) - прогнозное значение показателя RoRWA по клиенту на следующий «скользящий год» с учетом оценки доходности новой потенциальной кредитной сделки. В процессе моделирования учитывается оценка общей доходности клиента для банка, включая доход от кросс-продаж - дополнительных доходов банка при реализации конкретной сделки. Предложенная модель апробирована на одном из подразделений коммерческого банка. Результаты моделирования могут быть использованы при ценообразовании в процессе установления предельных значений маржинальности сделок для корпоративных клиентов, при оценке уровня рисков, принимаемых банком при реализации новых кредитных сделок, а также в процессе анализа альтернативных вариантов повышения доходности собственного капитала банка.
\end{abstract}

Ключевые слова: моделирование; оптимизачия; банк; общая доходность; кросспродажи; кредитные операции; финансовые риски; прогнозирование.

\section{Литература}

1. Jucan, C. N. Strategies for the Management of the Bank's Assets and Liabilities / C. N. Jucan // Annales Universitatis Apulensis Series Oeconomica. - 2009. - V. 11, № $1 .-$ P. 519-524.

2. Georgescu-Golosoiu, L. Financial and Banking Definitions / L. Georgescu-Golosoiu. Oscar Print, 2012.

3. Ionel, U. Analyzing Banking Risk / U. Ionel // @Ovidius» University Annals, Economic Sciences Series. - 2013. - V. 13, iss. 1. - P. 1549-1553. 
4. DeAngelo, H. W Liquid-Claim Production, Risk Management, and Bank Capital Structure: Why High Leverage is Optimal for Banks / H. DeAngelo, R. M. Stulz // Journal of Financial Economics. - 2014. - V. 116, № 2. - P. 1-50.

5. Slovin, M. B. The Value of Bank Durability: Borrowers as Bank Stakeholders / M. B. Slovin, M. E. Sushka, J. A. Polonchek // Journal of Finance. - 1993. - V. 48, № 1. - P. 247-266.

Мохов Вениамин Геннадъевич, доктор экономических наук, профессор, профессор кафедры математического и компьютерного моделирования, ЮжноУральский государственный университет (г. Челябинск, Российская Федерачия), mokhov50@mail.ru.

Катернога Яна Эдуардовна, магистр прикладной математики и информатики, ПАО "Сбербанк", (г. Челябинск, Российская Федерация), masnayayana@mail.ru.

Поступила в редакиию 1 декабря 2020 г. 